\title{
Screening of microorganisms for w-transaminase activity
}

\author{
Luciana Dalla Vechia $^{1,4}$, Raquel de Oliveira Lopes ${ }^{1,4}$, Thelma de Barros Machado ${ }^{2}$, \\ Ivana Correa Ramos Leal ${ }^{3}$, Leandro Soter de M. e Miranda ${ }^{1,4}$, Rodrigo Octavio \\ Mendonça Alves de Souza, \\ ${ }^{1}$ Grupo de Biocatálise e Síntese Orgânica,Instituto de Química -Universidade Federal do Rio de \\ Janeiro, CEP:22941-909 \\ ${ }^{2}$ Faculdade de Farmácia - Universidade Federal Fluminense \\ ${ }^{3}$ Faculdade de Farmácia, Campus Macaé - Universidade Federal do Rio de Janeiro, CEP:27930-560 \\ ${ }^{4}$ Programa de Pós-graduação em Química, Universidade Federal do Rio de Janeiro (UFRJ) \\ *lucianadallavechia@yahoo.com.br
}

Keywords: transaminase, kinetic resolution, biocatalysis

\section{INTRODUCTION}

Transaminases (TA) are pyridoxal phosphate dependent enzymes which are capable of transferring amino groups to achiral ketones. TA's can be used for asymmetric synthesis of amines and also for kinetic resolution of racemic amines. ${ }^{1}$

The aim of this work is to screen microorganisms for their $\omega$-TA activity for the kinetic resolution of 1rac-phenylethylamine (Figure 1).<smiles>[R]C([Y])[15NH]</smiles>

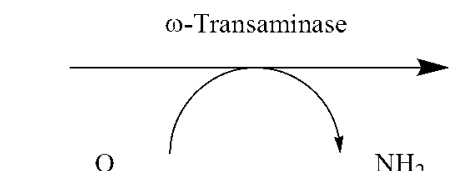

$\overbrace{\mathrm{R}^{\prime}}^{\mathrm{NH}_{2}}$<smiles>CC(=O)C(=O)O</smiles><smiles>CC(N)C(=O)O</smiles><smiles>[Z1]C([Z1])=O</smiles>

Figure 1. Kinetic resolution of rac-amines using microorganisms containing $\omega$-TA.

\section{RESULTS AND DISCUSSION}

We tested six Pseudomonas sp. strains ( $P$. alcaligens, $P$. putida, $P$. stutzeri, $P$. aeruginosa, $P$. fluorescens and $P$. oleovorans DSM 1045) and Janibacter terrae DSM 13953. The strains $P$. oleovorans and Janibacter terrae gave the most promising results. The kinetic resolution of racphenylehtylamine was performed using lyophilized cells previously cultivated in standard medium (glucose/bacteriological peptone/yeast extract). The cells were rehydrated with phosphate buffer containing PLP (pH 7.5) and then, were added of 1rac-phenylethylamine (1 eq) and sodium pyruvate (1 eq). The reaction mixture was shaken at $30{ }^{\circ} \mathrm{C}$ and $120 \mathrm{rpm}$ for 24 or 48 hours. Afterwards, the reaction was stopped by extraction with ethyl acetate. ${ }^{2}$ The organic phase was dried with anhydrous sodium sulphate prior GC analysis.

Conversions for all reactions were determined on a GC-MS cromatograph using a Rtx-5MS column (thickness: $0.25 \mu \mathrm{m}$, diameter: $0.25 \mathrm{~mm}$, length: 30 $14^{\text {th }}$ Brazilian Meeting on Organic Synthesis - $14^{\text {th }}$ BMOS - September 01-05, 2011-Brasilia, Brazil $\mathrm{m})$. The enantiomeric excess was accessed using GC-FID cromatograph using a chiral column BetaDex 225 (thickness: $0.25 \mu \mathrm{m}$, diameter: 0.25 $\mathrm{mm}$, length: $30 \mathrm{~m}$ ).

The results for the most promising strains evaluated $(P$. oleovorans and Janibacter terrae) are summarized in Table 1.

Table 1. Kinetic resolution of 1-phenylethylamine using $P$. oleovorans and Janibacter terrae.

\begin{tabular}{ccccc}
\hline Microorganism & $\begin{array}{c}\text { Time } \\
\text { (hours) }\end{array}$ & $\begin{array}{c}\text { Phenyl- } \\
\text { ethylamine } \\
(\boldsymbol{\%})\end{array}$ & $\begin{array}{c}\text { Acetophenone } \\
(\boldsymbol{\%})\end{array}$ & $\boldsymbol{e e}$ \\
\hline P. oleovorans & 24 & 13 & 87 & $80 R$ \\
& 48 & 18 & 82 & $90 R$ \\
\hline \multirow{2}{*}{ J. terrae } & 24 & 54 & 46 & $21 R$ \\
& 48 & 27 & 73 & $37 R$ \\
\hline
\end{tabular}

According to Table 1, good conversions and enantiomeric excess were obtained for kinetic resolutions using both strains. Furthermore, similar results were achieved with 24 or 48 hours of reaction. To reach better enantiomeric excess we are currently carrying on the reaction with a shorter incubation period.

\section{CONCLUSION}

Amongst all tested microorganisms, $P$. oleovorans and Janibacter terrae showed interesting results for the kinetic resolution of 1-racphenylehylamine. Further studies to improve the enantiometic excesses of these reactions and the screening of other strains are in progress in our laboratory.

\section{ACKNOWLEDGEMENTS}

CNPq and PGQU-UFRJ.

\section{REFERENCES}

${ }^{1}$ Koszelewski, D. et al. Trends Biotechnol., 2010, 28, 324.

${ }^{2}$ Clay, D. et al. Tetrahedron: Asym., 2010, 21, 2005. 